DOI: $10.21847 / 1728-9343.2020 .6(170) .218799$

\author{
VOLODYMYR KLAPCHUK, \\ Vasyl Stefanyk Precarpathian National University (Ivano-Frankivsk, Ukraine) \\ e-mail: volodymyr_klapchuk@ukr.net, ORCID 0000-0003-1788-794X
}

\author{
IGOR MAKARUK, \\ Vasyl Stefanyk Precarpathian National University (Ivano-Frankivsk, Ukraine) \\ e-mail:makiv45@gmail.com,ORCID 0000-0002-4928-4679
}

\author{
OLEKSANDR NOVOSIOLOV, \\ Vasyl Stefanyk Precarpathian National University (Ivano-Frankivsk, Ukraine) \\ e-mail:novo_a@ukr.net, ORCID0000-0002-1407-4508
}

LESIA POLYOVA,

Vasyl Stefanyk Precarpathian National University (Ivano-Frankivsk, Ukraine)

e-mail:polyovy@ukr.net, ORCID0000-0003-2971-5993

\title{
EXPLORATION OF OZOKERITE DEPOSITS ON THE TERRITORY OF AUSTRIAN GALICIA: SHORT HISTORICAL SURVEY
}

The article is devoted to the history of ozokerite mining in Galicia during the 19th - the first third of the 20th century. The historiography of the issue has been considered as well as the main scientists, who devoted their works to mineral description and forecasted ozokerite deposits on Galicia territory, have been highlighted. Having based on the presented studies, the volumes, technical supply and staffing of ozokerite industry have been revealed. Comparison of ozokerite deposits' investigation in different years has been accomplished due to comparative historical method. Moreover, structure and functions of ozokerite industry in Galicia, its external and internal connections have been analyzed. It was mentioned that ozokerite mines were in Boryslaw, Truskavets, Dzvyniachi, Staruni and other towns. Deposits of ozokerite-rich mineral were estimated in $30 \mathrm{ml}$ tons at the end of the 19th century. Boryslaw's mine was actively explored: up to 1.5-5 thou mines worked yearly where 2-10 tons of pure ozokerite were mined in 1850-1900-s. The peak of development was achieved at the last quarter of the 19th century where 10-19 thou tons were mined. At the beginning of the 20th century was a gradual decay of industry where only 2.6-3.5 thou tons of ozokerite were mined. The price of pure ozokerite had been constantly soaring from 280 to 1533 corona for 1 ton of mineral from the mid of 19th century. Annual ozokerite production varied between 200 and 500 tons in Truskavets, Dzvyniachi, Staruni. Due to ozokerite deposits' depletion and reducing demand on the international market, annual ozokerite production had decreased from 3.7 to 1.6 thou tons during 1900-1913-s and during the interwar period - up to 0.7 thou tons. Consolidation of mining companies led to production enlargement; as a result there were 20-25 mining companies and 2-3 processing plants in Galicia at the beginning of the 20th century.

Key word: ozokerite; mining; mine; Boryslaw; value; production; corona.

\section{Introduction}

Various medical products based on natural substances have been frequently used for treatment and improvement of public health at the current stage of healthresort industry. Namely, ozokerite or fossil wax is related to these natural substances. Unfortunately, scientists have not drawn attention to the history of emergence and development of ozokerite industry in Galicia during the last decades. Being lost in the time of Ukrainian independence, the industry can re-emerge that will permit to use ozokerite in natural state as well as in the medical

ISSN 1728-9343 (Print)

ISSN 2411-3093 (Online) products in health-resort industry and medicine in our country.

Fossil wax used for treatment as well as for candles production, was mentioned by the professor of Krakow academy Martin in his work "Herbarz polski, to jest o przyrodzeniu ziół i drzew rozmaitych i innych rzeczy do lekarstw należących księgi dwoje" (1595 p.). The author had described dense oil with sand contamination that "was flowing from the mountainous like a glue" that was collected in the wells; moreover some tough wax and bitumen that were a raw material from candles were pre- 
sented in chapter 13 "Asphalt, bitumen and Jewish bitumen". The records were disseminated by the French traveler Ph. Walter (1840).

A textbook of mineralogy and geology «Rzeczy koralnych osobliwe zdatniejszych szukanie, poznanie i zażycie» of the famous scientist, doctor of philosophy and free arts Ya. K. Kluk (1739-1796) was published in Warsaw in 1781-1782. The locations with dense oil, the methods of its extracting were presented in the book. The author distinguished oil, raw oil, tar, fat, balsam and thick types of oil (Jewish oil, gagatek, amber, nature fossil tar). He mentioned the sources of wax and possibility of its usage for lighting near the villages Rungury and Ropianka (Kluk, 1781).

B. Gakket in the work "Neueste physikalisch-politische Reisen in Jahren 1788 und 1789 durch die Dacischen und Sarmatischen oder Nordlichen Karpathen" (1788: 185) also mentioned regarding the sources of oil in the village Stara Sil and near the village Smolna (to the east of the village Dobromyl) where he had found brownish black oil in Menilite shales that could be processed and obtain a form of candle and was burning with brownish red flame. Regarding the origins of oil, B. Gakket supposed that it could have been created as a result of disintegration of animal and plants remains, oil and asphalt could have been appeared due to the process of thickening oil.

The famous natural scientist, doctor of law $S$. Staschyts presented a report of his journey of 1804 at a public meeting of the Warsaw Association of the Friends of Science (December $13^{\text {th }}, 1805$ ) that was published with the title "O ziemiorództwie gór dawney Sarmacyi a późniey Polski" (Warsaw, 1805). The following year, he published a geological map with the title "Carta geologica totius Poloniae etc.", where oil locations were marked. Staschyts reported in the explanatory memorandum to the map ("O ziemiorodztwie Karpatów i innych gór i równin Polski", Warsaw, 1815) about the numerous sources of salts, hydrogen sulfide, oil and its derivations (rock oil) on the surface along the northern-eastern slope of the Carpathian Mountains from Velychka across Dobromyl, Stara Sil, Drogobych till Kuty and further in Romania. Particularly, the author mentioned that rock oil was mined from three oil holes in Naguevytchy as well as in Pokuttia, having defined various types: clear yellowishgrey oil used for lamps and candles (fossil oil); blackishbrown oil that was burning darker with dense unpleasant smoke (ozokerite); solid brownish-dark bitumen (asphalt, tar) extracted a dense smoke while burning (quoted from Walter, 1840).

Particular legal acts regarding ozokerite exploration and mining were known from the beginning of $19^{\text {th }}$ century.

On August 2, 1810 a Decree of State Cabinet addressed to Mining Court in Drogobych was issued, where it was mentioned that all minerals that contained earth oil (oil and ozokerite) belonged to state property and could not be included into private land property. Permission for their mining was approved by the state (mining permission).

That governmental policy had a punitive effect on population that considered oil and ozokerite mining as some kind of income for their families. As a consequence of the protests of local population, Galicia Government proposed to cancel that decree. On November 8, 1810 a new decree was issued in Vienna, according to it oil was excluded from the list of minerals of state property and was remained in the property of land owners. Nevertheless, it did not concern ozokerite and asphalt that were left in state property.

The entrepreneur Ya. Mattis was the first owner of mining permission on fossil wax in Boryslaw given by Mining court in Drogobych in 1810. The companies' registration regarding oil and ozokerite mining and processing began from that time.

However, the exploration in greater scales was illegally performed by peasants, European entrepreneurs and sellers due to permission of the landowners. Such process of mining was looked like mining from the shallow pits (kopanky) performed by simple tools.

In $1810 \mathrm{~J}$. Gekker established Truskavets Mining Association of "Good Hope" for exploration of natural resources and mining of the silver-rich galena. In 1814 he founded a mine designed by $\mathrm{K}$. Schindler and named after St. Anna in Truskavets. Particularly, the author mentioned that there were deposits of asphalt and mineral water near Truskavets in his work "Geognostische Bemerkungen über die Karpathischen Gebirge in dem Königreiche Galizien" (Vienna, 1814).

The German scientist K.-F. Funke described the deposits of oil and mentioned about fossil wax mining near Drogobych as well as its usage for candle manufacture in his monograph "Naturgeschichte und Technologie" (Vienna, 1817).

The geology professor E.B. Push, who had performed the geological studies of Poland in 1817-1930, reported that the northern-eastern slopes of the Polish Carpathian Mountainous were rich for different minerals, in particular for rock oil and bitumen at the meeting of German natural scientists and doctors in Berlin in September 1828. The deposits of ozokerite in Boryslaw, Popeli and Truskavets were mentioned in the monograph "Geognostische Beschreibung von Polen sowie der übrigen Nordkarpathen-Länder" (Stuttgart, 1836); moreover, it was highlighted that it could be presented in the form of thin layers between shale and sandstone, and it was an oxidation product of rare rock oil.

In 1827 the administrator of state property $\mathrm{J}$. Mitsevskyi obtained an official permission for building a house for taking a bath and four houses for guests' accommodation.

All those events facilitated to scientific description of the origins, exploration and mining of fossil wax that was to obtain an official name. Actually, the modern name "ozokerite" was introduced into scientific usage by the Austrian mineralogist E.F. Glocker for Moldavian fossil wax for the first time in 1833 and later it was disseminated in the world (Tatomir, 1876).

Scientists-geologists and practitioners had been having an extended discussion regarding classification of Galicia's ozokerite for a long time. Having taken into account all classifications of his predecessors, the famous Polish scientist-geologist and paleontologist W. Szajnocha had defined the following differences of Galicia's ozokerite: solid wax, soft wax, wax with gray color, and soft black type of ozokerite (kinderbal) (Szajnocha, 1894, 118-140).

The chemical composition of all types of ozokerite differed. W. Szajnocha provided the data of other scientists who proved the results of V. Valter's analysis (1840). According to him, prof. Br. Palevskyi mentioned that ozokerite from Boryslaw had $85.85 \%$ of carbohydrate and $14.28 \%$ of hydrogen. Furthermore, he mentioned 
chemical compounds of Truskavets's ozokerite, it contained $84.46 \%$ of carbohydrate, $14 \%$ of hydrogen, 0.37 $\%$ of sulphur, $0.34 \%$ of organics and $0.86 \%$ of ash. Due to the data of prof. Golfschtedter according to Szajnocha's evidence, two types of industrial ozokerite contained such components: solid ozokerite $-84.94 \%$ of carbohydrate and $14.87 \%$ of hydrogen; soft ozokerite $85.78 \%$ of carbohydrate and $14.29 \%$ of hydrogen.

Regarding the size of Boryslaw's deposit, W. Szajnocha provided the data from E. Windakiewicz, who measured the deposit and defined the area of 73.5 ha (approximately $2100 \times 350 \mathrm{~m}$ ) in 1874; and K. Paul, who mentioned an area of 136.5 ha $(1950 \times 700 \mathrm{~m})$ in 1881 . The doctor Gassenpflug thought that the ozokerite deposit in Boryslaw had the size of $1500 \times 500 \mathrm{~m}$. and area of 75 ha, and depth of $200 \mathrm{~m}$. According to his calculations, the volume of natural resources in the deposit was $300 \mathrm{ml}$. tons, ozokerite resources - $30 \mathrm{ml}$. tons and after ozokerite mining with the rest of $10 \%$, its mass would be $3 \mathrm{ml}$. tons without taking into account earth oil (Szajnocha, 1894, 158-160).

If having considered the official data from 1873 to 1892, according to which 180 thou tons of ozokerite were mined, than its deposits in Boryslaw would have been sufficient for 300 years due to that output (Klapchuk, 2017a).

The scientific interest regarding description of the issue of ozokerite deposits on that area had not been urgent during the $20^{\text {th }}$ century. The new data about conditions of deposits, economics and perspectives of the usage were reflected in the publications of Engler, C., Höfer, H. (1909), Fr. Bujak (1910), as well as in various geological and economical manuals till the period of the Second World War (see, e.g. Skorowidz... 1906, 1912; Polski przemysł... Polski przemyst naftowy, 1934 and others), i.e. till the period when Galicia became a part of the USSR.

The historian interests to the issue of ozokerite deposits exploration was based on the facts that this mineral and its mining had created the preconditions for the fast regional development at the end of the $19^{\text {th }}-$ at the begging of the $20^{\text {th }}$ century (Klapchuk, 2017a, 2017b), as well as for some Galicia's infrastructure establishment and its recreational and touristic opportunities.

The purpose of the article is a complex study of geography, history of mining and ozokerite peculiarities if Galicia.

\section{Methods}

The method of periodization is applied for ozokerite deposits' investigation in Galicia, historical-genetic method is used for gradual reveal of technical supply and staffing of ozokerite industry, comparative historical method is applied for general comparison of ozokerite deposits' investigation in different years. Moreover, the elements of historical and systematic I.D. Kovalchenko's method (2003) as one of the main methods of historical investigation of industry for analysis of structure and functions, internal and external connections of ozokerite industry in Galicia are implemented.

\section{Research and Discussion}

On October 17, 1838 and November 30, 1840, the decrees of State administration in Vienna were accepted according to which dense oil with sand contamination, natural bitumen, asphalt and fossil wax had again been included into the sphere of governmental monopoly consequently any mining activity was possible only after obtaining an official permission. Such permission of new design was given to the founder of Truskavets resort $\mathrm{J}$. Mitsevskyi for the first time in 1838.

The chemical analysis of Truskavets's ozokerite was performed by the professor of organic chemistry and head of chemical laboratory in Paris F.N. Valter for the first time. The scientist came to a conclusion that ozokerite completely consisted of carbohydrate $(85.85 \%)$ and hydrogen (14.28\%), it was weakly soluble in alcohol and ether, sulphur did not react with it; temperature of melting was $59^{\circ} \mathrm{C}$. He proved the consequences of his predecessors that ozokerite and oil had the common genesis.

There were approximately 2 thou ozokerite mines in Boryslaw till 1850. Ozokerite was used for lightning necessity by locals at the end of the $18^{\text {th }}$ and the beginning of the $19^{\text {th }}$ century. Demand for it had been increasing and mining was soaring respectively. The center of mining was an area of Boryslaw town and the villages Dzvyniach and Starunia.

Small quantity of ozokerite in Galicia could be found in cracks (with volume up to dozen cubic centimeters) of Miocene-aged argillite and sandstone that located above salt deposits. The main ozokerite crack consisted of 14 smaller ones and located at a depth of $260 \mathrm{~m}$. was in Boryslaw.

In 1894 W. Szajnocha remembered that ozokerite was used particularly in household till 1855, when the archduke Ferdinand d'Este had a vacation in Truskavets and drew attention to the necessity of mineral's mining and widening sphere of its usage and selling (Szajnocha, 1894).

As a result, the radical changes in ozokerite mining occurred from 1855. The entrepreneur from Lviv P. Doms explored the vast deposits of ozokerite at insignificant depth near Boryslaw and began exploration the same year. Boryslaw's ozokerite has started its history from that moment. Nevertheless, from 1855 till 1860, ozokerite did not play a crucial role in Boryslaw, as there were long debates regarding its belonging to state monopoly that was prescribed by part 3 of General mining statute of 1854. The Ministry of Finance issued an order of December 7, 1855 that was no in favour of the entrepreneurs, due to which ozokerite mining belonged to the state monopoly.

However, near 1860 the necessity of ozokerite usage in chemical industry was known that had immediately increased its market value. That fact had forced the authorities to reconsider their attitude to the perspectives of ozokerite deposits' exploration.

Debates began in the public authorities. Ozokerite was again declared a state monopoly according to the order of the Ministry of Finance of November 16, 1860, and the Galicia Sejm accepted a declaration of April 25, 1861 according to which oil and other similar minerals were not to be included into the Mining statute, nevertheless they had to be mined with "positive consequences" for the local population and nature. The inconsistency in views caused singing of king's resolution of January 22, 1862 that ordered that fossil wax and earth oil were not considered to be subject to Mining Decree, however, were to be exclusively used for lighting. Consequently, the industrial development of the field was actually halted until further notice. The Ministry of Trade issued an order 
to cancel all pervious regulation acts and exclude ozokerite from the ban of Mining Decree on May 30, 1865.

It led to "ozokerite fever" near Boryslaw. Due to the reminiscence of the engineers Schubert and Yasinskyi, provided by the prof. Fr. Kotti, there were from 5 to 6 thou mines on the area of 15-20 morgs near Boryslaw and at least as large on the nearby areas. 4-5 thou workers were engaged in ozokerite mining who had mined 3-4 thou Vienna's pounds (168-224 pounds; 1 Vienna's pound $=56$ $\mathrm{kg}$ ) of ozokerite daily. As a result, yearly, according to the data of the engineer Yasinskyi, there were mined up to 90 thou Vienna's pounds of earth oil (more than 5040 ton) and 45 thou pounds of ozokerite (more than 2520 ton)

The prices on the obtained products by June 20, 1865 were the following (golden gulden for 1Vienna's pound): Bergöl (ordinary rock oil) -7.25 ; Bergwachs (ordinary ozokerite) - 7; Kenderbal (soft unpurified wax) - 4.2; Roppa (dense oil with sand contamination) - 2.0. Furthermore, Yasinskyi mentioned that the mine would be recouped in one and a half year with that pace of work (Klapchuk, 2017a).

It was therefore not surprising that a lot of entrepreneurs appeared in the outskirts of Boryslaw during a short period of time that had led to severe damage of environment. And the reason of it was abovementioned declaration of 1865 . An overwhelming majority of highly educated people and peasants remembered a declaration of the Galicia Sejm that had banned to damage environmental resources. About 1870-s, due to the data of Telezynskyi, 5600 tons of ozokerite and 11200 tons of rock oil to the value of $2.4 \mathrm{ml}$ golden gulden were mined near Boryslaw (Klapchuk, 2012).

Ozokerite used to be mined manually from rocks till 1878 , but had been melted out them since 1887. Still, ozokerite was manually extracted from the raw material at mines. In some cases when pure ozokerite was impossible to be extracted, a mixture was melting in huge pots till ozokerite had appeared on the surface. Subsequently, it was melting once again to be purified completely from all contaminations, after it was formed into the bars with sharp edges and in that form ozokerite came into the market. Raw ozokerite was processed with the help of sulphur and charcoal. Purified ozokerite had a name ceresin. Ozokerite's processing was performed in Czech Republic and Lower Austria.

The first attempts of Galicia's ozokerite processing were made at factory "Hochstetter i Comp." in Florisdorf near Vienna in 1867. Initially, only paraffin was extracted from ozokerite, but later in 1872 ceresin was obtained due to the activity of G. Ujgeli from Stokerau, Dr. Pilga from Carlsbad and F. Otto from Frankfurt am Main that had a crucial value for different spheres of economy. E. Zauerlandt and P. Zalozetskyi mentioned that $80-85 \%$ of yellow ceresin or $70-75 \%$ of white ceresin could be processed from the best samples of Galicia's ozokerite. E. Zauerlandt mentioned the annual value of ozokerite mining in Galicia at the level of $18 \mathrm{ml}$ deutsche mark, W. Szajnocha considered that figures were undervalued (Szajnocha, 1894). Till 1897 eight types of ozokerite were distinguished that depended on melting temperature, color, etc. Later, the State Bank of Austria-Hungary defined four types: "hochprima spezial" - of light color with melting temperature $68^{\circ} \mathrm{C}$; "hochprima" - of dark color with melting temperature $68{ }^{\circ} \mathrm{C}$; "normal" - of dark brown color with melting temperature $60^{\circ} \mathrm{C}$; "secunda" - of black color with melting temperature $52-56{ }^{\circ} \mathrm{C}$.

Generally, $1-2 \%$ of ozokerite was melted from the obtained material, and only $10 \%$ of general amount had commercial quality. The State Bank provided ozokerite selling. According to Fr. Bujak, $75 \%$ of all mined Galicia's ozokerite was used for ceresin production in Germany, Austria, Great Britain and Russia (Bujak, 1910: 176-177).

"Ozokerite fever" of the second half of the $19^{\text {th }}$ century led to foundation of 2.6 thou mines on the area of 100 ha (by 1865) in the outskirts of Boryslaw where were more than 5 thou workers. In 1872 there were 4500 mines and approximately 1260 companies; in $1874-4000$ and 854 respectively, were 10.5 thou people worked. However, in 1891 there were only 772 , and in 1900 - only 75 mines (Bujak, 1910: 172-173). According to the textbook of "Galicia's geography", in 1873 there were 12 thou mines in Boryslaw, 75 big and 779 smaller companies performed oil and ozokerite exploration, 10500 workers were engaged in total (Tatomir, ed., 1876:77). From the report of E Windakiewicz, it was identified that ozokerite production in Galicia was at the rate of 19653.7 tons and valued $3.5 \mathrm{ml}$ of golden gulden in 1873 (Windakiewicz, 1875: 11).

The chaotic mining and ozokerite selling in Krosnenskyi, Sianotskyi and other districts had forced the Ministry of Lands to delegate the mining commissar E. Windakiewicz to explore the situation. It should be mentioned that he had done meticulous work according to which the state obtained a real picture of mining industry in Galicia for the first time. Based on the situation, on December 19, 1873 the government submitted for consideration by the Galician Sejm a project of State Declaration regarding General Mining Decree of tar-rich minerals that would provide an opportunity to include earth oil and ozokerite into state monopoly. Nevertheless, that draft legislation did not find any support in the Sejm. And only on May 11, 1884 the Austrian government and on December 17, 1884 the Galician Sejm included fossil wax into land property, thus all local authorities could regulate the issues connected with mining of natural resources of that category.

It should be mentioned that earth oil and ozokerite mining was performed in two regions: Boryslaw (Boryslaw, Tustanovychy, Volianka, Truskavets); Nadvirna (Dzvyniach, Starunia, Molotkiv), still some mines were distinguished by their rich deposits.

The summary data from the work of W. Szajnocha regarding the mining volume in the locations are presented in the figure 1 below.

Ozokerite production began in Boryslaw in 1862 , however, the statistical data were practically absent till 1876. In 1876 mining volume was 93.5 thou kirtsi (approximately 12 thou tons), in 1880 - 106 thou (approximately 13.6 thou tons), in 1885 - (approximately 15.7 thou tons). Later, mining volume declined in two-four times across Galicia: in 1889-1894 - 64.3 thou kirtsi (approximately 8.2 thou tons), in $1898-77.6$ thou (9.9 thou tons), in $1900-20$ thou (2.6 thou tons), in $1905-29.6$ thou (3.8 thou tons), in $1906-27$ thou (3.5 thou tons), in 1907 - 25.1 thou kirtsi (3.2 thou tons) (Bujak, 1910: 170).

Ozokerite was mined in Dzvyniachi, Staruni (near Nadvirna) and in Truskavets, nevertheless the production was only $20 \%$ of all Galicia's ozokerite, in particular in Dzvyniachi: in 1896 - 350 tons, in $1901-258.4$ tons, in 1903 - 507.8 tons; in Staruni 287; 236.55; 84.65 tons, respectively (Engler, Höfer, 1909). 

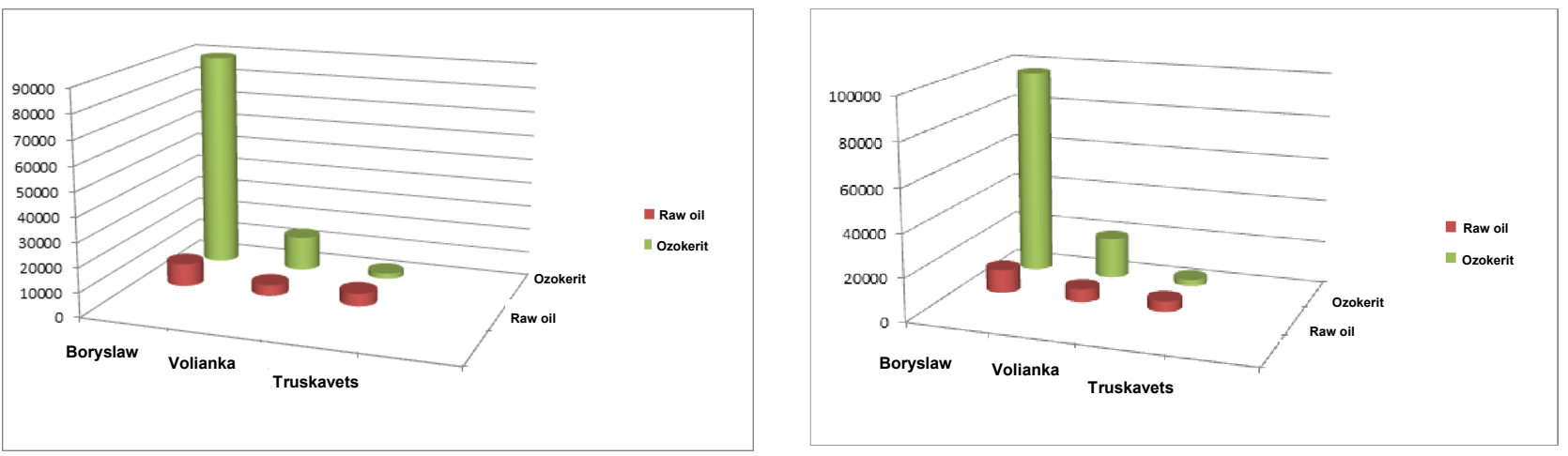

Fig. 1. Ozokerite and earth oil mining in Boryslaw's deposite (in pounds). On the left - 1883, on the right - 1884.

Despite decreasing in ozokerite mining, its price had been constantly increasing (corona for 1 korets) from the middle of the $19^{\text {th }}$ century till the beginning of the $20^{\text {th }}$ century: in $1865-28 ; 1876-50 ; 1885-60 ; 1890-57$; 1898 - 64; 1900 - 78; 1902 - 110; $1904-153,3 ; 1906-$ 1907 pp. $-124,3$. Consequently, the price had risen fivefold for half of a century. Value of all ozokerite production had fluctuations from 3.2 to $4.8 \mathrm{ml}$ corona at the beginning of the $20^{\text {th }}$ century.

The depth of mines had increased annually: from 2-4 meters in 1860-s to 10 meters in 1886, 60 meters in 1890 and 100 meters in 1900-s (Bujak, 1910: 172-173). Simultaneously, a number of mining companies had declined. In 1886 there were only 87 companies only in Boryslaw; in 1897 there were 47 in Galicia, including 23 in Boryslaw; in 1899 - 29 companies, in 1900 - there were 19 companies including 11 in Boryslaw and 8 in Starun and Dzvyniachi. In 1907 the quantity of companies had been reduced to 11 . The quantity of workers had been proportionally changed: in 1889-1897-s - 5-6.4 thou men; in 1900 - 2229; in 1906 - 3000; in 1906-1907-s - 2200 2300 men. The national structure was the following: Ukrainians - $1 / 2$ from the total amount, $30 \%$ - Jews, $20 \%$ - Polish (Bujak, 1910: 171-174).

There were primitive mines and mining tools, insanitary conditions were common in Galicia's ozokerite industry for a long time. Nevertheless, some particular mechanisms had been applied in the mines at the last quarter of the $19^{\text {th }}$ century.

All data regarding production state on Galicia's ozokerite mines and deposits' peculiarities have been summarized on the base of W. Szajnocha's work. During the period of 1886-1892, 102-124 mechanisms were used in the mines in Boryslaw, Volianka, Truskavets and 46556872 of men worked there. There were significantly fewer mechanisms from 8 to 26 and workers 199-396 on the mines in Dzvyniachi, Starun and Molotkiv. A tendency of decreasing quantity of employment had been followed in the first group of the analyzed mines during 1886-1892-s and simultaneously, increase in employment was mentioned in the second group of mines that indicated ozokerite exploration. Overall, the general quantity of workers declined from 7071 to 5039 in ozokerite mines in Galicia. Simultaneously, the quantity of applied mechanisms reduced on 19-21 items that had reflected a tendency of work mechanization in that period.
Ozokerite deposits near the earth's surface had rapidly depleted from the beginning of ozokerite mining, therefore the new technologies and mechanisms should be applied for search and exploration of new deeper mineralrich layers. Generally, the layers at a depth of 100-150 meters were developed; nevertheless, there were exceptions, for example, a mine in the tract "Potik" had a depth 208 meters and was one of the deepest in Boryslaw district in 1889. Industry born losses as the costs for mines' drilling had increased. E. Windakiewicz mentioned in his report that the single drilling costs were $6 \mathrm{ml}$. golden gulden (500 golden gulden for one mine), net incomes declined tenfold at the end of 1880-s (Windakiewicz, 1875).

The situation caused to mines' depletion tenfold, consequently in 1891 there were 468 mines in the outskirts of Boryslaw in contrast to 935 mines ten years before, due to W. Szajnocha. Only two enterprises financed by Galician credit bank and the French commercial company worked at full capacity (in the tract "Novyi Svit") that produced 2/3 of all ozokerite. However, ozokerite ceased to interest the French companies and all mined were sold to the Austrian Land Bank (Szajnocha, 1894).

The same situation was in Truskavets. 200-250 pounds of ozokerite were mined there monthly with general value of 500 thou golden gulden in 1890. Ozokerite mining had soared in Dzvyniachi region in comparison to all Galicia's regions due to the previous modernization occurred in 1868-1870-s (Polski przemyst naftowy, 1934).

Up to 8 thou tons of ozokerite were mined in Galicia in the last decade of the $19^{\text {th }}$ century, and only 3.7 thou tons in 1900 (Skorowidz, 1912: 358). It was connected with the depletion of ozokerite deposits as a result of inappropriate methods of their exploitation; demand reduction after a telegraph cable had joined Europe and America, where it was used as insulating material; technological advances in the process of oil extraction from paraffin that had become a valid replacement for ozokerite in many cases. Ozokerite mining technologies were outdated. At the beginning of 1880 -s it was predominantly manually mined from various shallow mines, as a result 9-11 thou employees were engaged in ozokerite industry in contrast to oil mining industry where only 4 thou men worked.

Overall, during 1873-1893-s it was a gradual depletion of ozokerite mining from 19.6 to 5.6 thou tons that was connected with decreasing demand for raw ozokerite and its substitution by refined oil products. When had a 
decline in production, a rise was observed in Dzvyniachi and Staruni especially during 1889-1892-s (Statystyka stanu kopalń i produkcyi ropy i wosku ziemnego w powiecie drohobyckim w roku 1883 // Górnik. - 1884. Tom III. - P. 35)

Except Boryslaw, Volianka, Truskavets, Dzvyniachi, Staruni and Molotkova, ozokerite deposits were explored in Siriach, Miatsyni Velykyi (Latsko district), Kobuliantsi, Klechanach (Novyi Sonch) and Mordavtsiach (Limanov district). There was no reason for their further development taking into account negligible deposits.

Production of Galicia's ozokerite mines was processed in small amounts in Galicia; the rest was transported to the different parts of Austria-Hungary and abroad (fig.2). Due to the data of P. Dobla (1885) the following amount (thou tons) was transported by the railway from Boryslaw annually in $1877-8.0 ; 1878-9.25$; 1879 - 9.64; 1880 - 9.457; 1881 - 8.165; 1882 - 8.28; $1883-8.3 ; 1884-11.0$.

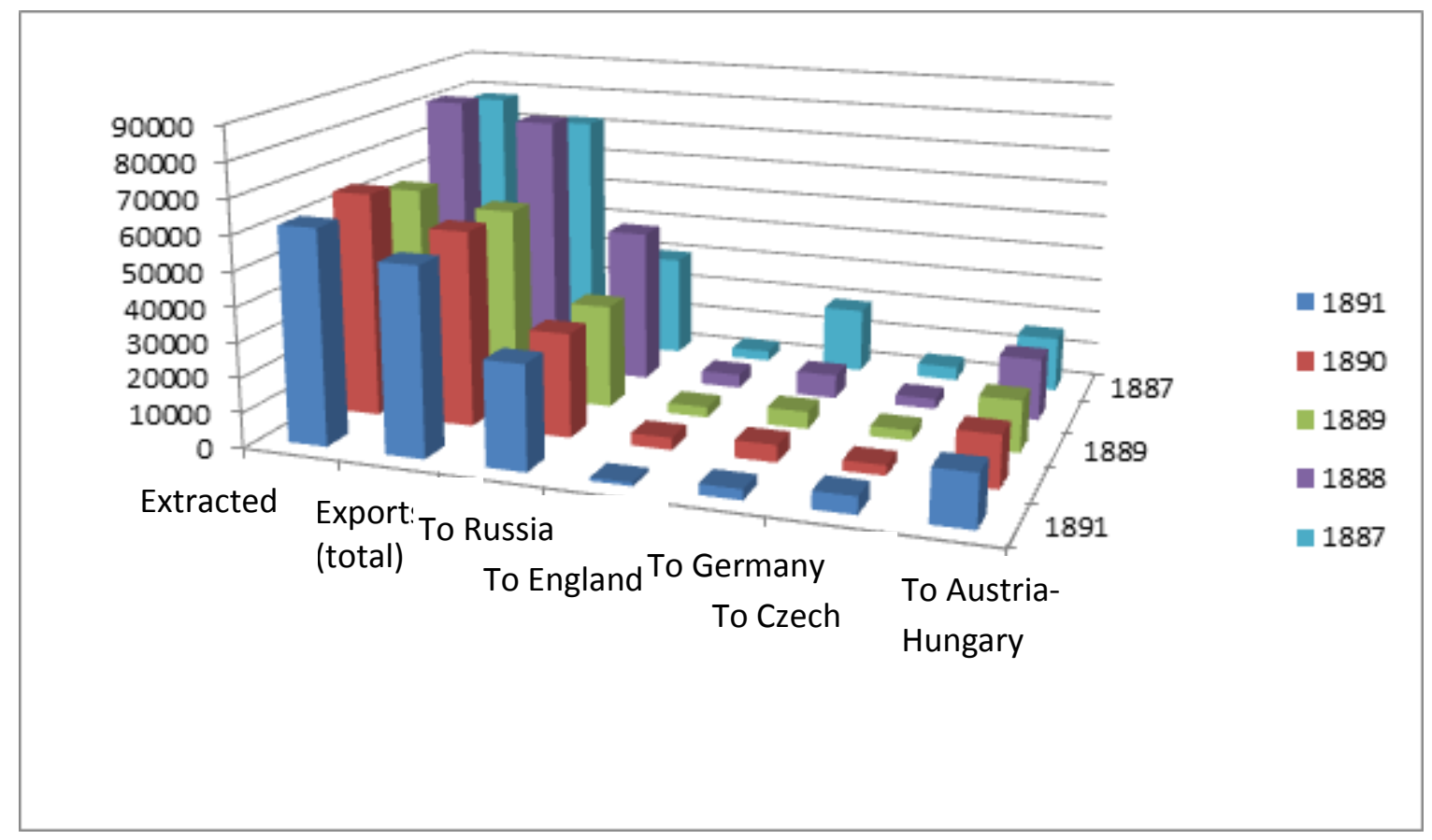

Fig. 2. Galicia's ozokerite mining and selling during 1887-1892 (figures presented in pounds)

The analysis has demonstrated that mined Galicia's ozokerite was predominantly exported (approximately 80$90 \%$ ) during 1887-1892. The largest export of ozokerite was into Russia, Austria-Hungary. The European countries, in particular, Great Britain, Germany, Czech Republic were a perspective market.

Ozokerite mining industry continued to decay at the beginning of the $20^{\text {th }}$ century, production decreased from 3.7 to 1.6 thou tons due to deposits' depletion and reducing demand on the international market in 1900-1913-s. Consolidation of mining companies had led to manufacture enlargement, as a result there were only two companies in Boryslaw: the Galician credit bank (with 70-100 mines) and "Boryslaw" (up to 100 mines). A mine in Truskavets belonged to Israel B. Vatman and two his companions employed 250 workers. The biggest mine "Good Hope" in Dzvyniachi belonged to M. Volfurt (125 workers employed), the second big company belonged to the firm "Lutsy and Company". The firm "K. Bogdanovych and Company" was on the first place in Staruni, where 250 workers mined ozokerite and pyrite (Klapchuk, 2012).

In 1906, 23 ozokerite mines officially worked in Galicia, according to E.Windakiewicz:

- joint-stock company "Boryslaw" specialized on fossi wax and oil mining in Vienna worked in Boryslaw and Dzvyniachi. 800 workers were employed in mine
"Boryslaw-1", 300 workers in "Boryslaw-2", 100 workers in "Dzvyniach".

- There were the following mines of Yakub Berech; the Galician Credit Bank (1153 workers); Gerscher Gerschels; Gubytska oil refinery; Josepha Kupferberga, Reginy Bergman, Gerscha Turteltauba and Association in Drogobych; Gerscha Mendelsona; Elgina Scotta and Karolia Bubera; Tumina, Schonbliuma, Liova and Community; J.B. Vagmana and Son in Boryslaw;

- Community "Concordia" (the owners - Golgammer, Vyschenskyi and Unger) in Drogobych;

- "Lilia Gelena" - a mine of fossil wax and rock oil in Starun (the owner - Kazymyr Bogdanovych and company); Abragam David Birkentgal, Marek Liab Schpigel and inheritors Chaskla Lorber; Henryk Kompes (Dusseldorf; mines "Kompes", "Meteor"); Gersh Fan, Pinkas Pfeffer, Abraham Fan, Meskulim Erich (tenants - Abraham Krigel in Solotvyn, J. Biorstling in Luneburg (Hannover); Aizek Schifter and company (tenants - Abraham Krigel in Solotvyn, J. Biorstling in Luneburg (Hannover);

- Nesser, Kammerman, Nemeriv, Gainberg, Kuchmerker, Oberlander in Voliantsia;

- Oil and wax mine "Ariel" (owner - Liab Lautman; 100 workes); "Spółka ogrodowa" (owners - Vladyslav, Antonina and Anton Lutsky, Dr. Yan Dylevskyi, Anna Pivnytska, Eugenia Strelbitska); "Good Hope" (owner - 
Modest Volfartova; tenants - Samuel Fritz Goltsapfel, Schymon Dische) in Dzvyniachi;

- Edward Merson (from Lviv) - in Molotkov;

- Israel Vagman, Isaak Diamantschtain and Eliasch Schiptsman in Truskavets;

- Dr. Arthur Goldgammer in Voronentsi (Nadvirna region).

The ozokerite melting factories of Israel Ber Vagman (in Boryslaw), Dachingera Menasche (in Truskavets) and Josepha Messera in Voliantsi (Tustanovytchi) were located in Galicia. Moreover, 15 entrepreneurs of Boryslaw were engaged in that business: Chaim J. Becher, Gersh Ber Bloch, I. Brunergraber, Gersh Nerscheles and S. Bloch, Solomon Gersh Gosiovskyi, Kalman Klingchoffer and company, Moizesch Klingchoffer, Moizesch Leker, Moizesch Leker and Jonash Maer, Moizesch Lents, Maer Mermelschtain, Gersch Mendelson, Solomon Rotman, Aaron Schpitsman, Moizesch Veber (Wykopaliska Staruńskie, 1914).

The mine "Camp i S-ka" of the Hamburg entrepreneur J. Kamp began to work in Starun ("Ropysche" district) in 1907, the treasured paleontological fossils of mammoth and rhinoceros were found in one of the mines (tract "Dmytrukove Pole") at a depth of 12.5 m [13, c. 14].

There were the following ozokerite mines in Galicia in 1912 (Windakiewicz, 1875):

- Yakuba Bechera; joint-stock company of fossil wax and oil mining in Vienna "Boryslaw"; Chaima Brunnengrabena; Erdgaima, Korngabera and Mendelsona; Gerscha Gerschelesa; wax mine "Konkordia" (owners - Joseph Kupferberg, Regina Bergman, Gersch Turteltaub and company); Tumin, Schonblium, Liov and company; wax mine and melting plant (owner - J.B. Vagman and son) in Boryslaw;

- Joint-stock company "Boryslaw"; oil and wax mines (owner Liab Lautman); Dr. Michal Lutskuy; "Spółki ogrodowej" (owners - heirs of Lutskuy - Antonina and Anton Lutskuy, Dr. Yan Dylevskyi, Anna Pivnytska, Eugenia Strelbitska) in Dzvyniachi;

Heirs of Yuliusch Henrik Kamp (Ernest Muller, Chaskel and Rachel Lorber); Henryk Kompes (Dusseldorf; mines "Kompes", "Meteor"); mines of fossil wax and rock oil "Lelia Gelena"; Krigl and company; Association Truskavets-Pomiarky in Starun.

\section{Conclusions}

1. Localization and deposits. Ozokerite was mined in Boryslaw, Truskavets, Dzvyniachi, Staruni and other cities in Galicia. Deposits were estimated in $30 \mathrm{ml}$ tons.

2. Ozokerite industry development. Boryslaw's mine was actively explored: up to $1.5-5$ thou mines worked yearly where 2-10 tons of pure ozokerite were mined. The peak of development was achieved at the last quarter of the $19^{\text {th }}$ century where $10-19$ thou tons were mined. At the beginning of the $20^{\text {th }}$ century was a gradual decay of industry where only 2.6-3.5 thou tons of ozokerite were mined.

The price of pure ozokerite had been constantly soaring from 280 to 1533 corona for 1 ton of mineral from the mid of $19^{\text {th }}$ century. Annual ozokerite production varied between 200 and 500 tons in Truskavets, Dzvyniachi,
Staruni. Due to ozokerite deposits' depletion and reducing demand on the international market, annual ozokerite production had decreased from 3.7 to 1.6 thou tons during 1900-1913-s and during the interwar period - up to 0.7 thou tons.

Consolidation of mining companies led to production enlargement; as a result there were $20-25$ mining companies and 2-3 processing plants in Galicia at the beginning of the $20^{\text {th }}$ century.

Acknowledgements. The presented results of study obtained due to the project work "Economic History of Galicia during the period of Austria-Hungary" (number of state registration - 0120U104585) that is performed within the limits of the salary fund of Vasyl Stefanyk Precarpathian National University.

\section{REFERENCES}

Bujak, Fr. (1910). Galicya. Lwow : Nakładem księgarni H. Altenberga ; Warszawa: Księgarnia pod Firmą E. Wende i Spółka. Tom II. Leśnictwo, górnictwo, przemysł. 509 s. (In Polish)

Engler, C., Höfer, H. (1909). Das Erdöl. Leipzig : Verlag S. Hirzel. Band. 2. 964 s. (In German)

Hacquet, B. (1788). Neueste physikalisch-politische Eeiscn aurch die Dacischen und Sarmatischen Karpathen. Theil III. Pag. 108. (In German)

Klapchuk, V. (2017b). Ozokerytovyi Klondaik Halychyny (kinets XIX - pochatok XX st.). Retrieved from http://photoIviv.in.ua/ozokerytovyj-klondajk-halychyny-kinets-xixpochatok-xx-st/. (Accessed 2020, October, 01). (In Ukrainian)

Klapchuk, V. (2017a). Ozokerytova lykhomanka. Vydobuvannia ozokerytu u Halychyni XIX stolittia Retrieved from http://photo-Iviv.in.ua/ozokerytova-lyhomanka-vydobuvannya-ozokerytu-u-halychyni-xix-stolitti/. (Accessed 2020, October, 03). (In Ukrainian)

Klapchuk, V.M. (2012). Rozvytok ozokerytovoyi haluzi u Halychyni XIX-XX st. Mandrivets, 4(10): 51-59. Retrieved from http://www.irbis-nbuv.gov.ua/cgi-bin/irbis_nbuv/cgiirbis64.exe?I21DBN=LINK\&P21DBN=UJRN\&Z21ID=\&S21REF$=10 \& S 21 \mathrm{CNR}=20 \& S 21 \mathrm{STN}=1 \& \mathrm{~S} 21 \mathrm{FMT}=\mathrm{ASP}$ meta\&C21C $\mathrm{OM}=\mathrm{S} \& 2 \_S 21 \mathrm{P} 03=\mathrm{FILA}=\& 2 \_S 21 \mathrm{STR}=$ Mandriv_2012_4_10 (Accessed 2020, September, 12). (In Ukrainian)

Kluk, Krzysztof (1781). Rzeczy koralnych osobliwe zdatniejszych szukanie, poznanie i zażycie. Vol.1. Warszawa: Drukarnia J.K.Mci i Rzeczyplitey u XX. Schol: Piarum (In Polish)

Kovalchenko, I. D. (2003). Metody istoricheskogo issledovaniya. Moscow: Nauka, 2003. 486 s. (In Russian)

Polski przemysł naftowy (1934). Lwów. Tabl. 56 (In Polish)

Skorowidz przemysłowo-handlowy Królewstwa Galicyi (1906). Lwow. S. 155-156. (In Polish)

Skorowidz przemyslowo-handlowy Królewstwa Galicyi (1912). Lwów. Wyd. II. S. 358. (In Polish)

Szajnocha, W. (1894). Płody kopalne Galicyi, ich występowanie i zużytkowanie. Lwów : Z drukarni W. Łozińskiego, 1894. Cz. II. Sole potasowe. Kopalnie i warzelnie soli. Wosk ziemny. S. 118-149, 158-160 (160 s.). (In Polish).

Tatomir, L. (ed.) (1876). Podręcznik geografii Galicyi. Lwów. (In Polish).

Walter, Ph. (1840). Note sur une cire fossile de la Galicie : Annales de chimie et de physique. Paris. T. 75. (In French)

Windakiewicz, E. (1875). Olej i wosk ziemny w Galicyi. Lwów. (In Polish)

Wykopaliska Staruńskie (1914). Kraków. 386 s. (In Polish) 
Володимир Клапчук,

Прикарпатський національний університет імені Василя Стефаника (м. Івано-Франківськ, Україна) e-mail: volodymyr_klapchuk@ukr.net, ORCID0000-0003-1788-794X

Ігор Макарук,

Прикарпатський наиіональний університет імені Василя Стефаника (м. Івано-Франківськ, Україна) e-mail:makiv45@gmail.com,ORCID 0000-0002-4928-4679

Олександр Новосьолов,

Прикарпатський національний університет імені Василя Стефаника (м. Івано-Франківськ, Україна) e-mail:novo_a@ukr.net, ORCID0000-0002-1407-4508

Леся Польова,

Прикарпатський національний університет імені Василя Стефаника (м. Івано-Франківськ, Украӥна) e-mail:polyovy@ukr.net,ORCID 0000-0003-2971-5993

\section{РОЗРОБКА ОЗОКЕРИТОВИХ РОДОВИЩ НА ТЕРИТОРІЇ ПІДАВСТРІЙСЬКОї ГАЛИЧИНИ: КОРОТКИЙ НАРИС ІСТОРІї}

Стаття присвячена історії видобування озокериту в Галичині у XIX - першій третині XX століття. Вивчено історіографію питання та визначено коло найбільших дослідників, які присвятили свої праці опису цього мінералу та прогнозуванню його покладів на території Галичини. На підставі цих досліджень послідовно розкрито обсяги, технічне та кадрове забезпечення озокеритових промислів. За допомогою порівняльно-історичного методу здійснено порівняння розробок озокериту на окремих родовищах і у різні роки. Крім того, проаналізовано структуру і функції, внутрішні й зовнішні зв'язки озокеритових промислів Галичини. Показано, що озокерит видобували у Бориславі, Трускавці, Дзвинячі, Старуні та ін. Запаси озокеритовмістної сировини за даними дослідників кінця XIX ст. оцінювалися у 30 млн. т. Найактивніше розроблялося родовище у Бориславі, де у 1850-1900 рр. щорічно діяло до 1,5-5 тис. шахт, які видобували 2-10 тис. т чистого озокериту. Максимального розвитку виробництво досягло в останній чверті XIX ст., коли видобувалося 10-19 тис. т. На початку XX ст. відбувався поступовий спад виробництва, коли видобувалося 2,6-3,5 тис. т озокериту. 3 середини до кінця XIX ст. постійно зростала ціна на чистий озокерит 3280 до 1533 корон за 1 т мінералу. Виробництво озокериту у Трускавці, Дзвинячі та Старуні коливалося у межах 200-500 т щорічно. Через виснаження покладів озокериту і зменшення попиту на міжнародному ринку щорічні видобутки у 1900-1913 рр. зменшилися з 3,7 до 1,6, а в міжвоєнний період - до 0,7 тис. т. Консолідація видобувних підприємств призвела до укрупнення виробництва, внаслідок чого на початку XX ст. у Галичині діяло 20-25 видобувних та 2-3 переробних підприємства.

Ключові слова: озокерит; видобування; шахта; Борислав; вартість; продукція; корона.

(c) Volodymyr Klapchuk, Igor Makaruk, Oleksandr Novosiolov,

Lesia Polyova

Надійшла до редакції: 22.09.2020

Прийнята до друку: 10.11.2020 